\title{
French studies: early medieval literature
}

Trachsler, Richard ; Birrer, Larissa ; Hess, Dominik ; Maillet, Fanny

DOI: https://doi.org/10.5699/yearworkmodlang.76.2014.0001

Posted at the Zurich Open Repository and Archive, University of Zurich ZORA URL: https://doi.org/10.5167/uzh-131897

Journal Article

Published Version

Originally published at:

Trachsler, Richard; Birrer, Larissa; Hess, Dominik; Maillet, Fanny (2016). French studies: early medieval literature. Year's Work in Modern Language Studies, 76(1):1-13.

DOI: https://doi.org/10.5699/yearworkmodlang.76.2014.0001 


\title{
ROMANCE LANGUAGES
}

\author{
II. FRENCH STUDIES
}

The place of publication of books is Paris unless otherwise stated

\section{EARLY MEDIEVAL LITERATURE}

\author{
RICHARD TRACHSLER, University of Zurich
}

This survey was compiled with the assistance of Larissa Birrer, Dominik Hess, and Fanny Maillet of the University of Zurich

\section{General}

Alain Viala, Une histoire brève de la littérature française. Le Moyen Âge et la Renaissance, PUF, $366 \mathrm{pp}$., is an attractive introduction to medieval French literature by a scholar better known for his work on later centuries. The selection of texts is based on the concept of 'cultural reference', i.e. on texts which function as artistic milestones, such as the Chanson de Roland, Tristan et Iseut, the Roman de Renart, or the Roman de la Rose. These titles, among others, are all covered in the first three chapters dealing with texts up to 1300 (pp. 1-112); the rest of the book is devoted to late medieval and Renaissance texts. Short excerpts, quoted in modern French, are commented upon, and the overall approach is sociological, offering information on genre and basic political, economic, intellectual, and religious events and facts, presented in a simple but not simplistic way.

Medievalism: Key Critical Terms, ed. Elizabeth Emery and Richard Utz, Cambridge, Brewer, xii +286 pp., consists of a series of 30 short alphabetically arranged chapters, written by specialists, defining key terms from Archive to Troubadour. Although the focus is mainly Anglo-Saxon and the material drawn from English rather than Romance studies, the volume is also of interest to scholars dealing with romance and the French Middle Ages.

History of the Discipline. Once again, this branch of our discipline has proved particularly productive, generating several edited volumes focusing on groundbreaking publications, established Romance-studies scholars, or on review chapters treating the present state of the discipline in a given country. Most studies take a biographical approach. This point is specifically addressed by Michel Zink, 'Un médiéviste dans la forêt du roman', pp. 15-24 of Le Savant dans les lettres, ed. Valérie Cangemi, Alain Corbellari, and Ursula Bähler, Rennes U.P., 286 pp., who draws a slightly ironic self-portrait and uses facts from his own biography to claim that scholars have always been attracted to fiction, letters, and imagination, so that many of them end up both producing and researching on literature. This tendency even gave rise to a genre in its own right in 19th-c. Germany: the Professorenroman, or a novel with a professor as protagonist. Alain Corbellari, 'Pourquoi mettre la philologie en biographies?', pp. 129-38 of Érudition et fiction. Troisième rencontre internationale Paul-Zumthor, Montréal, 13-15 octobre 2011, ed. Éric Méchoulan, Garnier, 327 pp., pursues the same line as Zink and others who take advantage of their own experience both as scholars and novelists to interrogate the relationship between fiction and science. Drawing on autobiographical backgrounds blended with many quotations from 
famous literary theorists, C. demonstrates that both poles inevitably join in the field of philology, and how therefore a biographical approach can be profitable when applied to the field of the history of the discipline.

Claude Fauriel et l'Allemagne. Idées pour une philologie des cultures, ed. Geneviève Espagne and Udo Schöning, Champion, 504 pp., is a study of Claude Fauriel (1772-1844), who in 1830, long before the first chair of French literature was established in France, was appointed professor of Foreign Literatures at the Sorbonne. He was responsible for a wide range of subjects, from Modern Greek to Old Norse, from Italian to German and Occitan. Although most of his findings and opinions were severely criticised by the ensuing generation of scholars, his influence was considerable in his time. Several contributions stress the importance of his work in a European context, and discuss his methods and their limits in several fields, both literary and linguistic. Of particular interest for French studies are Luc Fraisse, 'Fauriel et l'émergence des méthodes de l'histoire littéraire' (27-76), on methods of literary history, which did not then exist in French universities; Agnès Graceffa, 'Fauriel médiéviste: une approche culturelle du Moyen Âge' (77-92), on the approach to medieval studies, seen not only as a philological, but a cultural feature; Richard Trachsler, 'Fauriel et l'Histoire littéraire de la France' (137-50), on Fauriel's contributions to the Histoire littéraire de la France, in particular his attempt to link Arthurian literature to the South of France; and Dorothea Kullmann, 'Claude Fauriel et l'épopée' (191-242), on Fauriel's theories on epic literature, which he compared to Greek poetry. An appendix (461-75) provides a list of manuscripts regarding epic literature generated by Fauriel.

Patrick Moran, 'La poétique et les études médiévales: accords et désaccords', PerM (online), 35, presents an extensive overview of the use and impact of literary theory in medieval studies, especially French. Starting from the 19th c., when scholars studied literary texts as historical documents rather than works of art, the author comments on Vinaver, Zumthor, and then the different post-structuralist movements up to contemporary studies of manuscripts. He concludes that theory raises crucial questions concerning genre, the nature of the text, etc., which are still valid in the context of contemporary research.

In 1946, the Belgian scholar Robert Guiette published two articles that changed the way medievalists look at the lyric poetry of the Middle Ages. Jeff Rider, 'Introduction to Robert Guiette: Formal Poetry in France in the Middle Ages' and 'The Adventure of Formal Poetry', Revue électronique de littérature française (online), 8.1, a special issue entitled 'Speaking of the Medieval Today: French and Francophone Medievalisms', ed. Alicia Montoya and Vincent Ferré, gives a short presentation of the life and work of Robert Guiette and introduces his two famous essays, 'L'aventure de la poésie formelle', and 'La poésie formelle en France au Moyen Âge', together with English translations (78-91 and 92-100).

Mihaela Voicu and Catalina Girbea, 'Les "voies aventureuses" des études de littérature française médiévale en Roumanie', PerM (online), 35, offer a survey of medieval French Studies in Romania from its beginnings to the present day. The first holder of a chair of French literature was a pupil of Lanson, Charles Drouhet, who covered the entire field from the Middle Ages to the 2oth century. The first real medievalist was Sorina Bercescu, who struggled with the Communist regime and had to find ways of avoiding Marxist approaches when teaching. By the 1980s, a School of Medieval French Studies had emerged in Bucharest and, less prominently, also at the University of Cluj, even if no original books could be published for political reasons.

Manuscripts, Textual Philology, and Methodology of Text Editing. The study of autographs pits textual editors against a number of paleographic and codicological issues, since scribe and author converge, bestowing a specific authoritative status on one particular copy amongst others. Two monographs explore the field of medieval autographs, presenting 
the range of documents and texts of known autographs in the vernacular and Latin Middle Ages. They also reflect the possibilities offered by the study of autographs, which, in some cases, present different stages of a text and reveal the process of literary creation and correction. Although fewer vernacular manuscripts are known for the early medieval period, and although the hands of Charles d'Orléans, François Villon and the early Humanists have been explored more widely than those of their counterparts of the 12th and 13th cs, some useful evidence is available. Giuseppina Brunetti, Autografi francesi medievali, Rome, Salerno, 252 pp., presents a series of case studies arranged in chronological order. Starting with Frère Anger and Matthew Paris and ending with Jean de Montreuil and Antoine de la Sale, she not only offers a description of the known manuscripts and handwriting of the authors, but also assesses their work as a whole. Les Manuscrits autographes en français au Moyen Âge: guide de recherches, ed. Olivier Delsaux and Tania van Hemelryck, Turnhout, Brepols, 285 pp., provides students as well as specialists with the first synthesis, designed as a pedagogic guide, of French medieval autographs. The 'mode d'emploi' outlines the main possibilities for investigating the field of autograph manuscripts by asking three questions: how to identify them, how to edit them, and how to study them. The ensuing inventory represents undoubtedly the most innovative, useful part of the book: manuscripts are first ranked by author name, and then by type, depending on how testimonies have been produced and to what extent authorship has been involved. The volume ends with three reprinted and revised articles by Gilbert Ouy that dwell on 14th- and 15th-c. authors and show what conclusions can be drawn from the observation of their works for the assessment of punctuation, orthography, and grammar as pillars of the French linguistic system.

Francis Gingras, 'Le livre et le recueil', pp. 173-89 of L'Univers du livre médiéval. Substance, lettre, signe, ed. Karin Ueltschi, Champion, 384 pp., traces the history of the medieval practice of 'mise en recueil' with the help of medieval terminology as it survives in contemporary witnesses like glosses or inventories. Such a survey reveals a clear distinction between 'compilation' and 'book' (old French livre) and shows that different devices and factors, such as genre, form, language and authorship, are involved when it comes to gathering and arranging textual material. Genre is a particularly relevant criterion for assessing the unity (length, register, etc.), as well as the 'poétique des contrastes' (Zumthor), in other words, the contradictions that manuscripts sometimes display. Putting such subtle playful repetitions or contradictions forward, G. calls for an accurate, more nuanced consideration regarding the didactic-pleasing collections: 'mouvance' intervenes not only in medieval writing but also in the way of reading the same text.

Stylistics, Language, and Vocabulary. Transcrire et/ou traduire. Variation et changement linguistique dans la tradition manuscrite des textes médiévaux. Actes du congrès international, Klagenfurt, 15-16 novembre 2012, ed. Raymund Wilhelm, Heidelberg, Winter, vii + 296 pp., reflects on different readings (variae lectiones) in the textual tradition of medieval literary texts in Romance languages. The approach is valuable since specialists of variational linguistics do not usually consider working on this kind of corpus. Neither do philologists and editors of texts, who do not systematically include the diverging readings in their critical apparatus. The contributions cover most of the Romance languages, such as Catalan, Occitan, Old French, and Italian. Particularly relevant for French are Paolo Trovato, 'Da Gaston Paris ai New Philologists. Qualche riflessione sul trattamento della veste linguistica nelle edizioni di testi romanzi' (17-27), on how editors present the surface texts; Stephen Dörr, 'Textes d'autorités - autorité de textes' (29-37), dealing with whether texts and authors are quoted or not; David Trotter, 'Rudde et mal aourné langage. Les versions de La Fille du Comte de Pontieu' (41-51), on the relation of the two 13th c. versions of the novel of La Fille du Comte de Pontieu with the third, 15th-c. version; Jennifer Gabel de Aguirre, 'La Chanson de la Première Croisade d'après Baudri de Bourgueil. Manuscrits 
et variantes' (53-66) presents the textual tradition of Baudri de Bourgueil's Crusaders Epic; Richard Trachsler, 'L'Histoire au fil des siècles. Les différentes rédactions de l'Histoire ancienne jusqu'à César' (77-95) on the various redactions of the 13th-c. chronicle Histoire Ancienne.

\section{EPIC}

Beuve de Hamptone. Chanson de geste anglo-normande de la fin du XIIe siècle, ed. Jean-Pierre Martin (CCMA, 38), Champion, 524 pp., is a new critical edition of the Anglo-Norman version of Beuve de Hamptone replacing that of Stimming (Halle, 1899). Of the two major MSS, one (Louvain, Univ. Libr. G 170, ex Didot) was destroyed in 1940, obliging the editor to rely partly on Stimming's work. In comparison to the German editor, M. opts for a more conservative attitude and emends the text only where it is clearly faulty. The Anglo-Norman text is preceded by a thorough introduction, and accompanied by a translation into Modern French. The volume also contains an apparatus of critical notes, a glossary, and the usual indexes.

Ogurisu Hitoshi, 'De nouveau sur le texte du Roland d'Oxford: lecture', $Z R P, 130: 23-45$, is a report on the latest examination, with the latest technical means, of many questionable readings that arose while preparing the Édition électronique $d u$ Roland d'Oxford, enumerating slight errors and their cause (e.g. ink stains) and commenting on the rigorisme of some editors.

Phyllis Gaffney, 'Le géant à l'arc et l'enfant à l'olifant: contexte et sens d'un passage de la chanson de Mainet', Romania, 132.3-4:159-75, sheds light on nine lines of the chanson de Mainet, containing the description of King Braimant's tent, where there is a sort of a giant on one of the two poles, and a small child blowing into an ivory horn (olifant) on the other. Gaffney first situates the figures in their external context, seeing them as literary automata, before suggesting various possible figurative interpretations of the passage.

Peggy McCracken, 'The Wild Man and His Kin in Tristan de Nanteuil', Fabry-Tehranchi, Human and Animal, 23-42, examines Tristan's childhood in the forest, focusing on the opposition between the animal world, structured by social relations, and a human genealogy, marked by instinct and corporeality. By discovering sex and sexual desire, as well as by his training to become a knight, the wild man can return to his place within the noble genealogy of his family.

La Geste de Doon de Mayence dans ses manuscrits et dans ses versions, ed. Dominique Boutet (CCCMA, 19), Champion, 296 pp., gathers 15 contributions that interrogate the relevance of the concept of cycle when applied to the epic textual group known as Doon de Mayence cycle, the second of the three gestes according to Bertrand de Bar-sur-Aube's classification. The volume offers the first comprehensive survey of the so-called 'cycle des vassaux rebelles' considered from a philological point of view. Close attention is paid to the song of Gaufrey, so far rather neglected by critics; on a larger scale yet, the different studies intend to bring to light how the cycle was built and how it varies. The contributions are therefore arranged in three parts, starting with studies regarding three of the more important songs (Doon de Mayence, La Chevalerie Ogier and its suite, Renaut de Montauban), then discussing the issue of the codicological viability of the geste within specific manuscripts. The last part dwells on its rewritings and later adaptations.

\section{ROMANCE}

Catalina Girbea, 'Miles in Fabula. Des chevaleries dans le roman médiéval', CCMe, 225:35-59, looks at the term of 'chivalry' in medieval Romance from different perspectives and shows how it is caught in a tension between translatio and renovatio.

Chrétien de Troyes and Arthurian Verse Romances. Gerbert de Montreuil, La 
continuation de Perceval: quatrième continuation, ed. Frédérique Le Nan (TLF, 627), Geneva, Droz, 1192 pp., is a new critical edition, based on MS BnF fr. 12576 (A, or T, according to the more usual denomination), of the fourth Continuation of Perceval's adventures, also known as Gerbert de Montreuil's Continuation. In the two known manuscripts, Gerbert's text is inserted between the Continuation of Wauchier de Denain and the version by Manessier, which strongly suggests that Gerbert and Manessier wrote their texts simultaneously, unaware of the other's work. The editor has chosen to maintain the attribution to Gerbert de Montreuil, author of the Roman de la Violette, on the title page, although there is no decisive argument in favour, as she herself shows in the introduction.

Richard Trachsler, 'Héritiers et épigones. Les auteurs des romans arthuriens en vers après Chrétien de Troyes', Diaz, Héritages, 181-96, shows how the role of Chrétien de Troyes as the inventor of Arthurian romance was promoted by Wendelin Foerster at the end of the 19th c., and insists on the implication for modern studies on medieval romance. The presence of Chrétien's work as the hypotext of the entire tradition of Arthurian verse romance is essential for the modern intertextual approach dominant since the early 1970s. Foerster's view has never been challenged and many 'citations' identified by modern critics may also be explained in the light of a tradition common to both Chrétien de Troyes and later authors, as Gaston Paris, Foerster's only opponent, had suggested.

Leah Tether, 'Revisiting the Manuscripts of Perceval and the Continuations: Publishing Practices and Authorial Transition', Journal of the International Arthurian Society, 2.1:20-45, examines the manuscripts of Chrétien de Troyes's Perceval and its Continuations, paying special attention to the visible demarcations of authorial transition between the different texts. Using a theoretical framework regarding paratextual theory influenced mainly by Gérard Genette, the author aims to establish how these continuations were received amongst medieval audiences. To that end, she provides an analysis of the various ways in which the boundaries of authorship within the extant manuscripts corpus are noted.

Arthurian Prose Romance. As in the past few years, the Lancelot-Grail Cycle has attracted most of the attention of scholars active in the field of Arthurian Prose Romances: Le Roman de Merlin en prose (roman publié d'après le $m s$. A'-BnF français 24394), ed. Corinne FügPierreville (CCMA, 39), Champion, 496 pp., is a new edition, the third, of the prose Merlin, based on a manuscript of the so-called beta family. The introduction challenges the view that the versefragment is the source of the prose version, and argues instead that the contrary might be true. This point was made in 2004 by Linda Gowans regarding the Joseph, in an article that is quoted in the bibliography, but not mentioned otherwise. The Old French text is accompanied by a facing prose translation.

Patrick Moran, Lectures cycliques: le réseau inter-romanesque dans les cycles du Graal du XIIIe siècle (NBMA, 112), Champion, 720 pp., examines the nature of the 13th-c. cycle of Grail romances and shows, on the basis of theoretical considerations as well as case studies, that despite their autonomy, cyclical novels tend to constitute an intertextual network, creating thus a proper fictional space to be detected and explored individually by the reader.

Irène Fabry-Tehranchi, 'La fontaine bouillonnante et la tombe de Lancelot l'Ancien: Modalités textuelles et iconographies de la construction cyclique dans le Lancelot-Graal', $M A, 120: 331-75$, analyses the cyclical narrative as emphasised by the multiple appearances of the boiling fountain and the tomb of Lancelot the Elder in three different parts of the Grail cycle (L'Estoire del saint Graal, the prose Lancelot and the Queste del Saint Graal) in the text as well as in the iconography of the illuminated MSS. However, especially the latter focuses more on a series of related episodes than on the construction of a narrative cycle per se. 
Catherine Nicolas, 'Joséphés ou la Lettre de la Passion. Écriture de l'estoire et lecture historique dans l'Estoire del Saint Graal', Evdokimova, Moyen Âge, 131-44, examines the character of Josephus, son of Joseph of Arimathea, and the bishop chosen by Christ himself. To this spiritual authority the superposition of the Josephé with Flavius Josephus the historiographer adds a more factual one.

Jean-Paul Ponceau, 'L'Estoire del Saint Graal et la Queste del Saint Graal: un problème de chronologie relative', MedRom, 38.2:251-86, argues, contrary to the currently accepted idea, that the Queste del saint Graal was written after the Estoire del saint Graal. The Queste author seems to use the Estoire on several occasions, and some obscurities in the textual tradition of the Queste can be explained in the light of the manuscripts of the Estoire. Although there is no decisive argument for or against this view, the question is worth raising, since it has major implications for the elaboration of the Lancelot-Grail-Cycle.

An increasing number of publications address the Guiron le Courtois cycle, both from an exegetical and a text-critical point of view. Les aventures des Bruns: compilazione guironiana del secolo XIII attribuibile a Rustichello da Pisa, ed. Claudio Lagomarsini, Florence, Galluzzo, 620 pp., is the first publication by the 'Gruppo Guiron' team, which aims to publish a critical edition of the entire romance cycle of Guiron le Courtois over the next several years. The modern title Aventures des Bruns indicates a successful compilation (conserved in around 15 MSS) of mainly battle episodes extracted from the third branch of the cycle, the Suite Guiron (now conserved entirely only in MS Paris, Arsenal, 3325). The critical edition is based on the collation and recensio of all the MSS, from which a complete varia lectio is extracted. The introduction gives a rich codicological description of each of the MSS and a linguistic analysis. Based on stylistic and historical grounds, L. suggests the attribution to Rustichello da Pisa.

Lino Leonardi et al., 'Immagini di un testimone scomparso. Il manoscritto Rothschild (X) del Guiron le Courtois', Izzo, Narrazioni, 55-104 (with a French version, 'Images d'un témoin disparu. Le manuscrit Rothschild (X) du Guiron le Courtois', Romania, 132.1-2:283-352), comments on the recent discovery of a partial microfilm of MS X of Guiron le Courtois, whose present location is unknown. X contains an interesting continuation of the Roman de Guiron, the second branch of the Guiron-cycle, followed, on the last 3 folios, by a Franco-Italian suite that tries to complete the romance. In the first section, L. explores the history of the MS, which was part of the Rothschild collection until it was requisitioned by the Nazis in Paris during WWII. Nicola Morato explains the issues of the Guiron and its Continuation and shows that they were not written by the same author. Claudio Lagomarsini then analyses the language of the texts and suggests that the manuscript was produced in the Venice area, around 1350. Finally, Ilaria Molteni recognises in the illuminations of the manuscript the hand of the Guiron master, and suggests dating the completion of X some years before the masterpiece of the master, the Guiron in MS Paris, BnF, naf 5243.

Ilaria Molteni and Barbara Wahlen, 'Écrire et représenter la parole: le manuscrit de Guiron le Courtois, Paris, BnF n.a.f. 5243', Izzo, Narrazioni, 105-22, focus on Paris MS, BnF, naf 5243, a Guiron le Courtois produced for Bernabò Visconti, lord of Milan, around 1370. This MS, a masterpiece by the Guiron master, is richly illuminated, permitting an analysis of the relationships between the images and the text. The figure of Arthur is particularly interesting because it is related to the representations of Bernabò Visconti.

$R L a R, 118$, is a special issue dedicated to the Perlesvaus. Francis Gingras, 'Perlesvaus et le livre à venir' (27-52), discusses the status of the narrator in Perlesvaus ou le Haut Livre du Graal in relation to the authority of the written word and a postulated divine source. However, due to its narrative imperfections, Perlesvaus had difficult access into the manuscript tradition of the Grail 
compilations which generally preferred the romances of the Lancelot-Grail cycle, and accounted for the infrequent inclusion of Perlesvaus in these compilations. Patrick Moran, 'Perlesvaus et le canon arthurien: la construction de l'imprévisibilité' (53-72), sheds light on the position of Perlesvaus within the canon of Arthurian romance, showing to what extent this novel claims its fictional independence as compared to the logic of the Lancelot-Grail cycle to which it is linked. Patrick Henriet and Jean-René Valette, 'Perlesvaus et le discours hagiographique' (73-94) analyse the work for narrative elements that occur in hagiographic sources by taking into account the role assumed by hermits as well as relics (incl. the Grail), miracles and marvels. Éléonore Andrieu, " $\mathrm{Si}$ savrez le porcoi." L'Interprétation de l'Histoire dans le Haut-Livre du Graal' (95-116), distinguishes three historical levels in the narrative: the universal history of Christianity; its 'regional' version (e.g. the Christianization of Britain); and the history of the knights from the eponymous hero's family line going back until the Passion of Christ, and shows how this Christian conception of history and time is overcome in the novel. Alexandre Leupin, 'Le Perlesvaus, autodestruction du roman' (117-42), suggests that Perlesvaus is an anti-novel inasmuch as religious values traditionally upheld in Grail romance are falsified. Furthermore, by striving to explain all the secrets inherent in the Grail romance (e.g. the mystery of the bleeding lance), given the fact that the cyclical narrative is literally deprived of its mysteries, the production of ambiguous meaning that keeps the cycle turning is hence distorted.

Other Verse Romances. Sone de Nansay, ed. Claude Lachet (CFMA, 175), Champion, 987 pp., is a new edition of the anonymous verse romance Sone de Nansay, preserved in a single MS Turin, Bibl. Nazionale e Univ. L. I. 13, damaged by the 1904 fire but recently restored. Since Sone de Nansay is located in the central part of the volume, the text escaped severe damage. Approximately three quarters are legible, the rest being supplied from the edition by M. Goldschmidt (Tübingen, 1899), which predated the fire. The text is established according to modern criteria and accompanied by a lengthy introduction (pp. 1-145) which suggests, based on the sources used by the author, that the romance was written in the first half of the $13^{\text {th }}$ century.

Géraldine Toniutti, Pour une poétique de l'implication. 'Cristal et Clarie' ou l'art de faire du neuf avec de l'ancien, Lausanne, Archipel, 176 pp., examines the little-studied romance Cristal et Clarie, which contains a large amount of quotations taken from other romances or from the romance tradition. T. suggests that this feature is not due, as an earlier critic was inclined to think, to a lack of imagination on the part of the author, but to a different form of aesthetics, based on intertextual dialogue.

Robert S. Sturges, 'The Raw and the Cooked in Le Roman de Silence: Merlin at the Limit of the Human', Fabry-Tehranchi, Human and Animal, 43-56, discusses, within the anthropological frame of Lévi-Strauss and Wrangham, the border between human and animal, based on Merlin's appetite for cooked meat, before examining this same difference from an ontological point of view.

Maria Luisa Menighetti, 'Il ms ambrosiano D 55 sup. tra Francia, Oltremare e "Lombardia": illazioni su un percorso possibile', Izzo, Narrazioni, 15-23, studies the Milanese manuscript (M2 in Constans's edition), the oldest witness amongst the textual tradition of the Roman de Troie. It dates from the beginning of the 13th c., but its provenance is difficult to determine. Based on new palaeographical and iconographic elements concerning the initials, M. suggests that it was produced in Outremer.

\section{Lais, Fables, and Marie de France}

Pierre-Yves Badel, 'Guildelüec et la merveille. Sur des lectures nouvelles du lai d'Eliduc', ZRP, 130:269-315, presents a complete survey of attempts to explain the meaning of Eliduc and 
especially the role of Guildelüec in its final episode. The article questions the relationship between Guildelüec and Guilliadun and considers that the couple of loving women demonstrates the spiritual love proclaimed by Aelred of Rievaulx.

Bernard Sergent, L'Origine celtique des Lais de Marie de France (PRF, 261), Geneva, Droz, 392 pp., the first complete published survey on the Celtic origins of Marie de France's lais, adopts a methodical approach that consists in identifying, for each text, thematic, ritual, and etymological traces from Celtic mythology. The order of presentation follows MS London, BL, Harley 948, the only MS containing all twelve lais ascribed to Marie de France. Distinguishing the different substrates - Breton, Irish, Welsh, etc. -, S. suggests the presence of Celtic bedrock in every lai by Marie de France, but to various degrees.

\section{Didactic Works}

Marc Loison, Les Jeux littéraires de Raoul de Houdenc. Écritures, allégories et réécritures (NBMA, 111), Champion, 456 pp., discusses in detail the different aspects of Raoul de Houdenc's oeuvre (which includes romance and allegorical works), taking into account stylistic and poetological features as well as analysing the MS tradition. His work displays an écriture that plays with literary conventions, and very often this strategy of 'play' includes a strong authorial voice, later parodied by Raoul's readers and continuators: the closing part of this study considers the reception and rewriting of Raoul's literary heritage by Huon de Méry.

Exempla. Marie Anne Polo de Beaulieu, 'Le passage des recueils d'exempla aux langues vernaculaires. Nouveaux publics? Nouveaux usages?', Evdokimova, Moyen Âge, 359-75, gives an excellent survey of the exemplum tradition and the relation of Latin collections to their vernacular adaptions, showing that only two monastic collections were translated into vernacular languages, whereas the work of the Mendicant orders was largely adapted into several European languages and preserved in an impressive number of MSS.

\section{ROMAN DE RENART}

Benoît Chapuis, “'Se science est un ars de tel maniere”: le corps objet, médecine et chirurgie dans Le Roman de Renart', Reinardus, 25, 2013:36-52, analyses branches X (Renart médecin) and XXII (Coment Renart parfit le con) of MS M, paying particular attention to Renart's manipulative use of medicine and surgery, and concludes that the representation of the protagonist's skills is in accordance to the general knowledge of its 13th c. public, which emphasises Renart's supremacy in scientific matters even without recourse to his usual ruses. Evelyn Birge Vitz, 'Animal and Human Emotions in Le Roman de Renart', Fabry-Tehranchi, Human and Animal, 57-70, shows that, in spite of animals having 'human' emotions, their actions are still animal-driven and that the reader, unlike that of other textual genres, is invited to laugh at those animal emotions, not to share them.

\section{SHORT STORIES}

D'Orient en Occident. Les recueils de fables enchâssées avant les Mille et une Nuits de Galland (Barlaam et Josaphat, Calila et Dimna, Disciplina clericalis, Roman des sept sages), ed. Marion Uhlig and Yasmina Foehr-Janssens, Turnhout, Brepols, 2013, $x+465$ pp., collects studies on four collections of short tales that display the richness and originality of the narrative device of embedding inherited from the Eastern tradition: the Calila and Dimna drawn from the 
Panchatantra, the legend of Barlaam and Josaphat, the Seven Sages of Rome (or the Book of Sindibad), and the Disciplina clericalis by Peter Alphonsi. Of particular interest for our period are: Madeleine Jeay, 'La mise en scène du narrateur dans le prologue du Roman des Sept Sages de Rome (Paris, BnF, MS fr. 1553)' (147-64), who draws attention to the equivocal nature of the fables as a principle of composition, and illustrates the specific quality of this literature as distinct from the didactic and moral treatises with which it sometimes can be confused. The emphasis placed here on the multiple possibilities for meaning of fictional narrative introduces the third section of the volume, which highlights the infinite mutability of embedded tales: Mary B. Speer, 'What Ails the Sodomite King of Egypt? 'Senescalus' in the K Sept Sages de Rome' (193-207), deals with the French verse tale 'Senescalus' found in the Seven Sages of Rome. The study of the tale's rewriting from the Eastern source in the Book of Seven Viziers sheds light both on this enigmatic anecdote and the text of the Seven Sages. Amy Heneveld, 'From Paternal Advice to Amorous Dialogue: Reading through the Frame of Fabular Exchange' (209-29), considers the appropriation to courtly usage of classic apologues, such as 'The Man and the Serpent' and 'The Archer and the Nightingale'. Inserted in a partly polemical amorous dialogue, the Donnei des amants, these two exempla share a dynamic of 'fundamental reversibility', which, far from harnessing the tales in a single moral, reveals their potential polysemy. In the fourth section, two contributions based on the manuscript compilation Paris, BnF, MS fr. 1553, consider the unique copy of the oldest French verse version of the Seven Sages (Yasmina Foehr-Janssens, 'De Jérusalem à Rome: le Roman des Sept Sages dans le manuscrit de Paris, BnF, MS fr. 1553', pp. 329-49) and Gui de Cambrai's version of Barlaam and Josaphat (Marion Uhlig, 'Un voyage en Orient: le Barlaam et Josaphat de Gui de Cambrai et le manuscrit de Paris BnF, MS fr. 1553', pp. 351-73), each contained in this same MS. The two studies focus on manuscript context and on the ambiguous relations that the compilations establish with the traditions of antiquity and the East. Finally, Nancy Oddo, 'Les enjeux des réécritures de romans orientaux au temps de la Réforme catholique en France' (409-31) and Barbara Selmeci Castioni, 'La Bible comme accessoire: le potentiel d'équivocité de la légende de Barlaam et Josaphat sur la scène française du xviıre siècle' (433-49) examine the long-term dissemination in France of Barlaam and The Seven Sages, the latter being printed in the 16th c. with the title Histoire d'Erastus.

Cris de Paris and Rues de Paris. Laurent Vissière, 'Goûter la ville. Réflexions sur la poésie ambulatoire de Paris au Moyen Âge’, Evdokimova, Moyen Âge, 277-92, offers comments on the small, but well documented genre of the Cris and the Rues de Paris, and stresses the fact that these texts never focus on monuments, but rather aim to capture the atmosphere of a given street or place. Most of these texts have come down to us in single manuscripts, and, as the author suggests, might be the work of Parisian clerics writing with a comic or satirical intent.

Fabliaux. Natalie Muñoz, Disabusing Women in the Old French Fabliaux, Berne, Lang, $138 \mathrm{pp}$., examines the role of women in the fabliaux and argues that the genre is less misogynistic and anti-feminist than previous scholarship had suggested. It examines in particular the manipulation of language by women and the closing moral which frequently serves to reassert traditional male dominance, thereby reducing, according to the author, any uneasiness the audience may have felt.

Fanny Maillet, 'Les fabliaux dans la Bibliothèque universelle des romans, ou comment s'accommoder d'un lourd héritage', Diaz, Héritages, 69-88, analyses material and moral issues that govern the transmission of the so-called fabliaux in the 18th c., especially in the Bibliothèque universelle des romans, and shows how this periodical contributed to the classification of the literary genre and played an important part in the discovery of short medieval texts and their sources. 
L'Étude des fabliaux après le Nouveau recueil complet des fabliaux, ed. Olivier Collet, Fanny Maillet, and Richard Trachsler, Garnier, 288 pp., contains nine contributions examining the medieval fabliaux and their modern reception. Alain Corbellari, 'D'un recueil "complet" à l'autre. Les répertoires de fabliaux, de Montaiglon-Raynaud au NRCF' (15-37) compares the lists drawn up from Montaiglon and Raynaud's collection to the NRCF. C. identifies constants in criteria formal, narrative, axiological - that govern the inclusion or exclusion of texts, but also identifies variants that indicate the subjectivity necessarily involved in any attempt to classify short narrative. Behind its apparent search for objectivity in determining the genre of the fabliau, the $N R C F$ is no exception. Fanny Maillet, 'Quand les fabliaux étaient en liberté: Barbazan, La Curne, Paulmy', (39-62) deals with the first editions and collections of fabliaux, including the pioneering work of Barbazan, and shows how the rediscovery of these texts during the second half of the 18th c. led to different approaches amongst scholars, ranging from faithful reproductions of manuscripts to free rewritings. The definition of the fabliaux appears to be more flexible than today but also clearly influenced by the material available. Marco Veneziale, 'Aux origines d'un canon. Les Fabliaux ou contes de Le Grand d'Aussy' (62-91) focuses on modern translations of fabliaux, from 18 th c.-attempts to the most recent works. The examination of such a corpus reveals which fabliaux have become major publishing successes and which have remained unknown to the public. Much of the analysis is devoted to the very successful Fabliaux ou contes by Le Grand d'Aussy, which supplied the source for many other translations from the 18th c. to the present. Olaf Posmyk, 'Les traductions allemandes de fabliaux' (93-116, looks at German translations of the fabliaux from the 19th c. to the present, in the light of the influence of the compilation by Montaiglon and Raynaud. They show a more or less clear intention to distinguish different genres by opposing the dit to the lay or fabliau. The multiplication of approaches in these translation, ranging from the search for an archaic tone or national models, to overt attempts to instruct or entertain, is illustrated by examples of translations that constantly reflect the problem of terminological actualisation. Anne Cobby, 'Chains de pute coroie, fel et deputaires: les injures dans les fabliaux' (119-39) observes the increasing number of studies, especially by linguists, of insult and invective in general, and addresses this question in the fabliaux, taking into account the vocabulary of the insults, and more generally the context in which they take place. For this purpose, she exploits the possibilities offered by the NRCF through the examination of their variance - quite important in this case - within the manuscripts. Romaine Wolf-Bonvin, 'De L'huis à éclipses à l'ouvroir du diable: l'imagerie de la porte dans les fabliaux', (141-62) analyses the representation of the motive of the door (porte and huis) in the fabliaux by gathering their occurrences, which the NRCF facilitates. She suggests that the physical threshold of the short narrative marks the passage from the anonymous social sphere to an individual one. Doors and gates point towards an entire interior world which holds the women of the fabliaux prisoner and calls for the transgression of the intimate space, be it the domestic world or the female body. Rosanna Brusegan, 'Les fabliaux en performance et le rire de l'évêque' (163-93) approaches secondary orality by analysing spatial deixis in a selection of fabliaux where speech, together with other deictic processes, delimits a performance space in a burlesque or parodistic manner. In the three fabliaux examined, discursive entities (speaker, interlocutor) appear at various levels, working as a metaphor of the creative act. Luciano Rossi, 'Tout en étant incontournable, le Nouveau recueil complet des fabliaux est-il vraiment irréprochable?’ (195-222), points out three major weaknesses of the NCRF: the absence of historical perspective, the ecdotic principles, and the lack of codicological information, suggesting numerous historical and philological revisions and new attributions and calling for a more general discussion on the legitimacy of the corpus established by the NRCF. 


\section{LYRIC}

Davide Checchi, "Fin'amor" e "amour soufisante" nella lirica arrasiana del XIII secolo', MedRom, 38.2:287-327, examines the heterodox nature of Jehan Bretel's chansons, in which the poet expresses his frustration relative to the precepts of courtly love, and favours a love ideology founded on a more pragmatic value, in opposition to the ideology accepted by more traditionalist trouvères. The jeux-partis and other verses composed by some poets close to Jehan Bretel do contain similar views, expressed by coherent topics and vocabulary. These texts proclaim a more pragmatic view of love as opposed to the traditional fin' amors. This new love ideology, termed amour soufisante, can be placed within a general anti-courtly tendency of Arras literature, whose cause might be explained by historico-sociological parameters.

\section{Religious Literature}

Denis Piramus, La vie Seint Edmund le rei, ed. Delbert Wayne Russell, Oxford, ANTS, 287 pp., is based on a second, earlier manuscript of Piramus (Manchester, John Rylands Library, MS French 142), containing substantial new textual material and being some 900 new lines longer than MS London, BL, Cotton Domitian A XI, which was used for all five extant editions to date but ends very abruptly.

Maurizio Perugi, Saint Alexis, Genèse de sa légende et de la 'Vie' française. Révisions et nouvelles propositions. Accompagnées d'une nouvelle édition critique de la 'Vie' (PRF, 262), Geneva, Droz, 800 pp., is a complete study of the Alexius tradition in Latin and its vernacular adaptation. This new edition of the French Vie de saint Alexis sheds light on the many similarities that exist between the French text and the Latin version (Rythme sur Saint Alexis) circulating mainly in the Austro-Bavarian region and most likely prior to the vernacular version. Other chapters deal with the Greek archetype of the legend, giving an overall picture of its genesis.

Vladimir Agrigoroaei, "Rara avis": la traduction française médiévale du "Barlaam et Ioasaph" du Mont Athos', MedRom, 38.1:106-51, re-examines the partial edition of MS. Mount Athos, Iviron, 4583 (II, 149) (Ancient Greek text and French translation) by Paul Meyer in 1866 by re-editing in particular fols. 131v-133r, concluding that the translation remains close to the original text in both style and syntax, and dates it between 1206 and 1210.

\section{Folklore, Anthropology, and Cultural Issues}

Mireille Demaules, 'Symbole zoomorphe et personnification dans le récit de rêve médiéval', Demaules, Personnification, 53-70, examines the evolution of the 'symbolic language of the dream' in French medieval literature. D. analyses the dream's place in both epic and romance literature, which mainly display an animal symbolism, and in allegorical texts, which exhibit mostly human personifications, showing the interferences between the two patterns of representation, and points out some major steps in the evolution of the poetical representations of dreams, particularly the reception of the Consolation of Philosophy of Boethius and the Roman de la Rose. Jean-Marie Fritz, 'Personnifier les parties du corps: scandale ou carnaval?', ib., 129-44, deals with 'marginal cases' of personifications, those concerning body parts (especially pudenda). Personifications of this kind appear mainly in three minor literary genres, the débat, the encomium, and the fable, from which F. extracts his examples (along with fabliaux and other short stories defying definition). The author concludes that body personifications do not posit a transgressive position 
but rather play with the codes of allegorical writing. Carlos Fonseca Clamote Carreto, 'Contez, vous qui savez de nombre...' Imaginaire marchand et économie du récit au Moyen Âge, Champion, $376 \mathrm{pp}$., deals with the analogies between words and money and examines the parallels between literature and economy, in a corpus consisting of $c .70$ epic and courtly texts from the 12th and 13th centuries. The author underlines similarities between the literary and the monetary function of the merchant and the poet, and concludes that language, merchant activity, monetary signs, and sexuality constitute a coherent network of analogies.

Travel Writing. L'Estoire de la guerre sainte, ed. Catherine Croizy-Naquet (CFMA, 174), Champion, 1027 pp., is a new edition of this Crusade epic transmitted in a single manuscript and a short fragment. It is superior in all regards to the recent attempt by Marianne Ailes and Malcolm Barber (Woodbridge, 2003) which remains valuable nevertheless for its accompanying English translation. The edition closely follows MS Vatican, Reg. Lat. 1659, whose Anglo-Norman features are maintained throughout the text. The edition, however, does take into account the very numerous corrections already suggested by Gaston Paris, the first editor of the text (1897), and the reviewers of the Ailes-Barber edition. The introduction discusses the attribution to a potential author by the name of Ambroise, quoted in the text, but in a context more likely to cite a source rather than the Estoire itself. The introduction as a whole provides a very complete discussion of both the literary tradition and the historical and geographical facts.

Catalina Girbea, Le Bon Sarrasin dans le roman médiéval (110o-1225), Garnier, 671 pp., looks at the image of the good Saracen in medieval romance from 1100 until 1225, examining the relation between the good Pagan and chivalry, along with the edifying dimension of romance, to show why many Pagans are valued, embraced, pampered or raised to role-models in a literature addressed to Christian warriors. Throughout the text, comparisons are made with three German romances, in order to validate the universality of the good Saracen as a narrative category.

Marion Uhlig, 'Chrétiens mangeurs d'hommes et urbanité païenne dans la Chanson d'Antioche: l'excitatorium en question', Romania, 132.3-4:353-76, analyses the episode of the maneating Tafurs in the Chanson d'Antioche and the shocking reaction of the Saracens, contrasting it with that of the Christian Franks, who show no sign of disapproval whatever. Thus, contrarily to other chansons de geste, the ideological paradigm of 'us versus them' is alienated and sees the (Christian) reader's solidarity towards his own camp diminished.

Bestiaries and Animal Lore. Laura Endress, "How the "cerf sanz tache" Found Its Way into the Vulgate Cycle', Reinardus, 25, 2013:78-95, examines some examples of white stags in a corpus of texts relating the founding legend of the Norman abbey of Fécamp, and aims to shed light on the progressive christianization of the white stag on its evolutionary path towards the 13th-c. Vulgate Cycle, and especially the Suite Vulgate of the Merlin Romance.

\section{PERFORMANCE}

Le Jeu d'Adam, ed. Christophe Chaguinian, Orleans, Paradigme, 222 pp., is an edition based on the unique MS (Tours, Bibl. Mun. 927) of the oldest vernacular medieval play (together with the Auto de los Reyes Magos), accompanied by a translation into modern French, and two critical analyses of the language of composition, probably Anglo-Norman (by Catherine Bougy), and the responsories giving evidence of a liturgical usage of this oeuvre (by Andrea Recek).

Véronique Dominguez, 'Medievalism and Medieval Theatre: About Adam', Revue électronique de littérature française (online), 8.1:115-33, while mainly concerned with the relation between medieval studies and medievalism, contains numerous interesting observations on the staging of adaptations of medieval European theatre on the 2oth-c. stage, especially in England and France. 
On the French side, the article closely examines Gustave Cohen's Jeu d'Adam et Eve staged at the Sorbonne in 1935, which is compared to the York Mysteries adapted in England in the 1950 s by Martin Brown. More theoretical and contemporary views on medieval theatre, ranging from Brecht to Novarina, are also considered.

\section{Themes And Motifs}

Olivier Delsaux, 'Les plaintes des écrivains français contre le vol intellectuel ou matériel de leurs textes', Evdokimova, Moyen Âge, 307-24, attempts to verify, on the basis of textual tradition and surviving codicological evidence, the complaints of certain authors about the damage to their work caused by theft of manuscripts or careless scribes. Examples range from the Vie de Thomas Becket to late medieval authors.

Hélène Haug, 'L'histoire de la lecture médiévale. État des recherches et inventaire des sources', Evdokimova, Moyen Âge, 325-36, gives a detailed and informative survey of sources for the study of reading in the Middle Ages. The sources are arranged by category: documentary sources such as inventories and testaments, then manuscripts and books bearing traces of medieval reading, followed by accounts of reading in narrative, and finally iconographic evidence depicting scenes of reading or lecturing.

Hélène Dupraz-Rochas, 'Plaisir littéraire et éthique aristocratique. Éclairer la philologie par l'histoire', Evdokimova, Moyen Âge, 117-30, examines the tension between the ethical purpose claimed by a large number of texts and the equally present call for pleasure exhibited in the prologues of other works. The latter tendency can be explained by the growing influence of an aristocratic readership that overtly encouraged the production of texts with scopes different from those favoured by the Church. 